\title{
Negotiating womanhood: the bird metaphor in Southern African folklore and rites of passage
}

\author{
Jean-Marie Dederen \& Jennifer Mokakabye \\ Jean-Marie Dederen is a senior lecturer in the Centre for African Studies at the University of Venda. His \\ research involves the study of symbolic representations in the indigenous cultures of the Vhembe region. \\ Email: dederenj@univen.ac.za \\ Jennifer Mokakabye is a candidate in the M. A. Archaeology programme at the University of Venda. Her \\ project explores the meaning of animal symbolism in hunting societies. \\ Email: mokakabyejennifer@yahoo.com
}

DOI: dx.doi.org/10.17159/2309-9070/tvl.v.55i2.2934

\section{Negotiating womanhood: the bird meta- phor in Southern African folklore and rites of passage}

In spite of its evident presence in Southern Africa's rich cultural heritage, the bird metaphor has received surprisingly little attention. The cultural materials analysed in this article include children's stories, songs, heroic poetry and ethnographic accounts of rites of passage. At first the data seems to suggest that bird symbolism could be interpreted in terms of a simple dual conception of gender identity. Some magical birds signify the prowess and authority of men. Others could be linked symbolically to the procreative powers of women. On further reflection, however, we identified a third category of more ambiguously gendered birds. It is contended that this additional bird type can be explained in terms of the female-male dialectic that shaped gender relations in small-scale societies. It is further proposed tentatively that the bird metaphor could have provided women with a symbolic means to negotiate their identity. Keywords: animal symbolism, bird metaphor, folklore, gender constructs, rites of passage.

\section{Background}

This article explores the gendered meaning of the bird metaphor. The ideas that are suggested here derive partially from data collected previously, more particularly during two sessions of fieldwork in the Limpopo province. Research in 1995 and 1996 in the Vhembe district focused on initiation symbolism and involved Venda elders from both sexes (see Dederen, "A Dog with a Collar ... Field notes on an 'indigenous wedding gown'"). In the second half of the nineties and again between 2001 and 2003 just over a hundred children's stories were recorded and debated with their female narrators. The oral literature project also produced songs, two of which are discussed in this article.

Approximately one out of five narratives included magical birds amongst its protagonists. Moreover, half of the avian beings expressed some form of affinity or association with either women or men. Inspired by these preliminary findings we decided to explore further the contribution of bird symbolism to the social construction of gender identity in folklore and in the closely related realm of rites of passage.

Our understanding of the data is shaped and driven by the disciplines in which 
we have been trained (Anthropology and Archaeology), as well as by our interest in gender. In terms of methodology we made use of textual and socio-cultural analysis. The investigative process combined three perspectives. Bird symbolism was first scrutinised within the particular stories or rituals in which it functioned. It was then compared to data from other stories and rites, before being contextualised within the wider socio-cultural background from which it stemmed.

In our analytical efforts we have been inspired by the basic theoretical premise that gender conflict is as essential an aspect of the human condition as is balance (see Biesele 180-5; Turner 23; Guenther 148-59). Moreover, we understand gender essentially to be "a primary way of signifying relationships of power" (Scott 42).

In addition to the fieldwork data mentioned above, the cultural materials that are examined here originated from published folklore collections (Hertslet; Keyser; Lestrade; Stefaniszyn; Kunene; Jordan; Scheub; Corbeil; Hewitt; Makgalo, Mothuši and Makopo; Lemekoana and Masola; Biesele; Guenther; Bennun; Mashilo, Mashilo and Mampuru; Kruger and Le Roux) and from a number of ethnographic studies of rites of passage (Van Warmelo; Stayt; Krige and Krige; Richards; Turner; Silberbauer; Blacking; Corbeil; Davison; Keeney and Keeney).

The seven tales that provide the core of the discussion have been presented in an abridged format. Titles, it was generally agreed by the oldest narrators, are a modern introduction. Our sample of narratives has been sourced from different cultural areas: Venda (tale one), Zulu (tales two, three and six), Tsonga (tale four) and Xhosa (tale seven). The San narrative (tale five) may appear to be the odd man out. However, its symbolic references to the cosmological importance of water manifest a belief complex that has been shared by hunter-gatherers and farmers alike (Heintze; Hoff; Bernard; Guenther 128). The story belongs to a body of creation myths which are commonly referred to as the adventures of the Early Race (Bennun 15-54). Additional cultural materials that are examined here include stone and wooden sculpture, children's songs, hunting songs, heroic poetry and traditional medicine. They represent the cultural heritage of Shona, North and South Sotho and Ambo speaking peoples.

The ethnography of three female initiation schools has been particularly informative for the purpose of exploring the ritual function and meaning of the bird metaphor, namely the Chisungu of the Bemba (Richards; Corbeil); the Lovedu Byali (Krige and Krige); and the Venda Domba (Blacking). Their curriculum consisted of songs, sacred and secret formulae, dance and the acting out of symbolic performances (Blacking 149-77). The teaching socialised the young female novices into normative marital and sexual behaviour (Van Warmelo 52).

The article can be roughly divided into two parts. Firstly, we define the different types of magical birds that have emerged from the cultural materials under study. Some birds personify masculinity. Others align themselves with the social realm of women. A third category was found to be more ambiguous in nature and seems to 
defy a simple binary classification. In the remaining section we revisit the ambiguous category in order to demonstrate that the bird metaphor can be explained, at least partially, in terms of the principles of reciprocity and tension that characterised the social interaction between women and men in small-scale traditional societies (Begler).

We would like to emphasize the tentative nature of our inquiry and its conclusions. Symbols are multi-vocal and therefore open to a variety of investigative angles (Turner 50). The analysis of oral literature and ritual pedagogy is an uncertain and challenging task on account of its fluid nature and its fragmentary data (Guenther $162,165)$. Our interpretive efforts certainly do not exhaust the exegesis of the narratives and rites of passage that form the subject matter of this essay.

\section{Birds and masculinity}

Several of the magical birds that have been encountered in the stories, we would like to suggest, clearly signify the personality features that were traditionally associated with hunters and warriors. These violent metaphors of masculinity appeared even in stories that were designed for the smallest of listeners. In the first folktale the narrator recounts one of the many adventures of Tortoise.

Tale one: "Tortoise defeats Lightning Bird" (Keyser 9-18)

After Tortoise has crafted himself a reed flute at the river, Lightning Bird descends from the sky, his home, and asks Tortoise to be his music teacher. When he has finally mastered the instrument, he disappears with it into the sky. Whirlwind takes Spider high up into heaven so that he can spin a ladder for Tortoise to get back his flute. Lightning Bird destroys the ladder, but with the help of his friends Tortoise eventually, after some more ruses, manages to return to earth.

Tortoise portrays "the wisdom of the little ones", a standard theme in Southern African folklore (Junod 223). The two main protagonists try to outwit one another, as hunters and warriors do. They both personify masculinity. The powerful Lightning Bird represents the vigorous warrior and the dominant ruler. His little adversary exemplifies the prowess and stealth of the hunter. The two avian manifestations that appear in the Zulu narrative of "uCilo" act likewise (Krige 362). The plot revolves around a small bird who has challenged the great Eagle in a contest for the kingship. Again, the mighty ruler of the sky is outsmarted by a small hero, probably much to the satisfaction of the child audience for which this story has been crafted.

The portrayal of the Lightning Bird and Eagle, we presume, is inspired by the traditional beliefs in a Supreme Being, a powerful male deity who was believed to inhabit the sky. This sky being was said to have manifested himself in the form or in the company of a mythical bird-of-heaven or sky-bird (Eiselen 262-9; Berglund). Perhaps, the eight magnificent soapstone bird sculptures excavated at Great Zim- 
babwe are manifestations too of the supreme sky being, or of its bird messenger. Significantly, some of the carvings display lips and toes instead of beaks and talons. Garlake was the first to notice and explore their anthropomorphic features.

In another tale, the prowess of the hunter-warrior, which constitutes the central theme, is befittingly expressed by references to the slaying of warriors; the tracking and hunting of mysterious animals; the hardships of an epic journey and the fight against a horde of cannibals.

Tale two: "Seven birds and seven boys" (Hertslet 18-30)

A king has lost seven of his boys in battle and it is the task of the only remaining son, Kulume, together with his companions, to track the seven magical birds that have been sent by the ancestors to replace and, eventually, bring back to life his brothers. In his search for the birds Kulume has to travel over distant mountains, cross hostile forests and rivers, employ stealth and display bravery when facing a horde of man-eaters.

Kulume must prove his tracking and fighting skills in order to capture the magical birds that will be transformed into his slain brothers-in-arms. After he has successfully completed his adventurous journey, Kulume is ready to join his older brothers-the magical birds—as a soldier on the battlefield.

The adventures of the young prince, we think, symbolise his rites of passage into manhood. The brotherhood of warriors could be a reference to the initiation schools which in real life prepared boys to become members of age regiments. Boys were socialised into the realm of hunting and fighting at a young age. They participated in stick fight competitions and trapped birds in the vicinity of their home, or ventured outside the village armed with their miniature bows and woodtipped arrows. In the following two songs birds are mocking the youths who have failed to catch them:

We are nestlings

We stay in the nest

We are shy to fly

We are shy to fly

Shame on you boy!

You wanted to catch us

So that you can eat us with your meal

Today you will eat a meal without meat

Your mothers will be back soon

When they return they will scold you

Can you catch us? Purr! [sound of flying] shame on you! (Venda song, Tsianda, Limpopo) 
And:

Boys of ga-Ramodumela, hea

As soon as they see me, hea

They made some sticks, hea

They threw them at me, hea

They threw them in the sand ... (North Sotho song, Mohlabaneng, Limpopo)

The bird metaphor does not always depict the warrior or the hunter directly. At times birds are linked to the realm of men in a more discreet and indirect manner. Such is the case with the following two tales in which the narrator cautions young women not to defy or disobey their future spouses.

Tale three: "The woman and the mighty bird" (Jordan 226-35):

The story is set during a spell of extremely cold weather and the women of the village must spend long hours collecting firewood. Only the deepest and darkest section of the forest provides plenty of dry wood. Women have been forbidden by their spouses to enter the dark grove. A young and beautiful woman ignores the warning. Upon entering the forbidden section of the forest she is offered a bundle of wood by a giant bird. She agrees not to tell her husband. Every day she receives wood and lies, until her husband threatens to kill her. After the woman finally confesses, the tall trees from the grove surround the house and the mighty bird swallows the woman.

And:

Tale four: "The woman who stole the eagle" (Tsonga story, Malamulele, Limpopo) A certain man goes on a hunting trip and shoots a big eagle. He instructs his wives to cook it. They are told not to eat the bird. After she has secretly eaten all the meat, the youngest wife puts the bones back into the pot. On his return the man questions his wives in vain. With the help of a diviner the culprit is identified and killed.

The woman who is punished for stealing the meat of her husband's quarry, the eagle, is the youngest of the co-wives. We suggest that on the one hand the eagle has been selected by the creator of this very popular story to define male identity in terms of the authority of the husband. On the other hand, the bird of prey also signifies virility through its behavioural affinity with the hunter.

Hunter-prey identification constituted a central theme in the hunting songs of the Ambo (Zambia). Avian predators appeared in these songs as images of the hunter, and the hunting grounds were often compared to a battlefield. The songs celebrated the psychological strength and physical energy of the hunter. They emphasized the hardships of life in the bush and were said to shape the identity of a true man (Stefaniszyn).

Likewise, in South Sotho heroic poetry (Kunene) birds of prey were used routinely to praise epic warriors. The poems detailed the qualities of carnivorous birds and 
emphasised their association with death. A warrior slain on the battlefield was called an ox abandoned to the vultures and a dispute between men was said to be settled by the vultures. A number of birds were selected to signify virility: vultures, eagles, hawks, crows and yellow kites. Lightning, thunder, hurricanes and hailstorm-common metaphors for the sky deity-accompanied the valiant warriors in combat.

Bird metaphors were linked to masculinity in rites of passage as well. In the Bemba Chisungu initiation school instructors handled two particular types of didactic clay models (generally referred to as Mbusa) that symbolically represented husbands and warriors. These ritual clay objects (mwansa cembe, the white eagle, and cembe, the eagle) portrayed male feathered hats. In Bemba society, feathered hats once signalled the marital status of young husbands. Ceremonial hats also honoured the bravest on the battlefield (Corbeil 31, 36-7, 46 and Richards 104, 203). Five more virile avian creatures have been mentioned by Blacking in his comprehensive ethnography of the Venda Domba initiation. They will be briefly examined.

\section{Birds and womanhood}

In our understanding, the bird symbolism of indigenous storytelling betokens either female or male gender identities. Whilst masculine bird metaphors were readily identified and understood by us, the exact nature of the association between birds and the realm of women proved at first to be less discernible. A closer look at girls' rites of passage and indigenous world-views rendered its meaning more transparent.

First, initiation ceremonies customarily defined womanhood in terms of procreativity and motherhood and primarily aimed at guiding the young novices into sexual maturity, marriage and childbirth (Stayt 112; Turner 23). Mystical birds, we detected during the analysis of the data, mediated this journey of transition. In doing so, we would like to propose here, their symbolic presence fostered, confirmed, honoured and celebrated the young mothers-in-the-making. Secondly, the cosmologies of Southern Africa symbolically linked life-potency to a mystical pool (Heintze; Bernard). Creation mythology described how the first humans had emerged from it; rites of passage at times re-enacted the creation and its symbolism manifested how the fertility of the initiates was closely associated with it (Keeney and Keeney 66-7; Blacking 87-9, 160, 231). In the following two tales the affinity between water, the source of all life, and human procreativity constitutes a salient theme:

Tale five: "The Blue Crane and the waterhole" (Bennum 110-2)

Whilst searching for Frog, Blue Crane is killed by two lions. Her brother looks for her remains, but only recovers one small bone. He picks up the bone, drops it in the waterhole and leaves for his camp. Later he finds his sister splashing in the water. After seeing her he returns home. Days pass by. On his second visit to the fountain he looks at her basking in the sun and notices how she has grown. After he arrives back in the camp he makes new clothes for her. On his next visit he can see that she has 
become a young woman. He does not want to startle her and leaves. Finally, he decides to fetch her. She does not recognise him at first. He offers her a new cap, a kaross and an apron and together they walk back to the camp.

The Blue Crane, one of the people of the First Race, was looking for her friend Frog who had left his house in a confused state of mind. She was determined to find and assist him. This narrative, it has been suggested but not explored further by Hewitt (169), symbolically describes the rites of passage of a young San woman. Like the Blue Crane, the female novice is temporarily removed and isolated from society. Like the mythical bird she metaphorically "dies" (ends her childhood) and "grows" into a young woman. She is "reborn" as a young adult when being released from initiation. The presentation of a cap, kaross and apron resemble the handing over of new clothing to a girl after the completion of her rites of passage. Throughout Southern Africa new garments were meant to publicly confirm a young woman's change in social status. They also expressed her readiness for marriage (see Blacking 99-100; Davison 159-60; Van Warmelo 76).

The Zulu tale of "Sikhamba-ngenyanga" revolves around the themes of female fecundity and motherhood.

Tale six: "Sikhamba-ngenyanga" (Jordan 236-44; Hertslet 66-7)

A wealthy man rejects his beautiful spouse after she fails to produce a child. One day, whilst she sits near the river, two doves arrive and instruct her to swallow magical pellets. Soon she gives birth to a girl. The birds request river pebbles as payment for their intervention. The child remains hidden until she reaches puberty. To protect her, it is decided to let her move about only by moonlight (hence the name "she-who-walksby-moonlight"). The father of the girl decides to look for a husband from a wealthy family for his daughter. The in-laws are told that she should work only by moonlight. They ignore the warning and made her fetch water during the day. The girl is taken by the river. The two doves return and demand the sacrifice of an ox. Its carcass is thrown in the river. She is then released from the water again.

Two pigeons have come to the rescue of a barren woman on behalf of the spiritual forces of the river. The significance of the bird metaphor, we presume, is emphasized by its appearance at the beginning and the conclusion of the story. There is an additional reference to the procreative powers of water in this tale, namely the slaughter of an ox and the disposal of its remains in the river. This type of ritual was traditionally organised to safeguard or to restore the fertility of the land (see Krige 24-48). The narrator uses pebbles to link the doves, and their mediating role, to the image of the river. The image of the moon-once a symbol of procreative powers and a common honorific reference to the bride (Biesele 191; Hewitt 205)—reiterates the theme of womanhood. 
Doves and other smaller bird types regularly appear in folklore as the allies of young women. In a charming Pedi story a dove saves two female siblings, Ping and Pinyana, from cannibals (Lemekoana and Masola 16-22). Doves do not only protect young women, they personify them, too. Amongst the Northern Sotho, wooden images of doves were traditionally used to mark sites for girls' puberty rites. The bird carvings that had been placed on top of the wooden enclosures around the initiation school were said to symbolize the novices (Witt 13).

The white egret of the Chisungu girls' rites of passage, we believe, served the same symbolic purpose as the Blue Crane and the magical birds in the story of Sikhambangenyanga. This particular water bird personified the female initiates, expressed the procreative powers of young mothers-in-the-making and mediated the mystical forces of the river pool (Richards 89-90; Corbeil 108-9).

We found additional support for the affinity between water birds and motherhood in the medicinal use of the stork amongst North Sotho speakers. We were told that after certain parts of the stork (lentlopodi) had been burnt, its ashes were mixed with an ointment and rubbed into small incisions on the baby's forehead and upper parts of the neck. According to M. M. M. at Ga-Ramokgopa, the mixture was said to facilitate the fusion of the cranial bones and to prevent thema, a dreaded disease that was believed to kill young infants. Thema, intriguingly, was described as a masculine bird of prey. Both cure and disease, in other words, were associated with gendered bird metaphors. We will return to the tension or the opposition that possibly existed between the water and sky birds in the final section of this article.

Fat from a python, another mystical water creature, was also customarily used for the protection of newborn babies. It constituted a main ingredient in rain making medicine. Python skin was wrapped around the waist of women who experienced problems in giving birth, according to A. M. Munyai.

Lastly, the stork's symbolic connection with female fecundity and motherhood, we argue, could have been inspired by its seasonal migration. Every year water birds returned to their habitat (pools, wetlands and rivers, i. e. places filled with life potency). Migration occurs during spring, which is the season of nature's rebirth, when rains rejuvenate the earth and plant life. Moreover, as confirmed by D. Engelbrecht from the University of Limpopo, water birds generally produce more eggs than other bird species. Perhaps, this behavioural anomaly could have been interpreted traditionally as evidence of the birds being "more fertile".

\section{An ambiguous bird category}

So far we have suggested that water birds can be distinguished from sky birds in terms of their gendered association. Our dual classification, we assume further, marked some of the main traditional concerns around which the social identities of women and men were being constructed, namely female procreativity or mother- 
hood, and masculine prowess and authority. On closer scrutiny a third, more fluid gendered category emerged from the data. Intriguingly, in several folktales birds that ally themselves with the plight of women have been defined as large and terrifying, therefore as masculine sky beings.

Tale seven: "The girl who defeated the drought" (Scheub 406-11)

The heavens had dried up and as a result rivers and wells had disappeared. Man and beast suffered alike. One day a little girl ventures into the mountains in search of water. There she encounters a mighty bird. The bird gives her water and instructs her not to tell anybody. Back in the village she is asked whether she has found any water. She replies: "No!". Every day she gets water from the bird who cautioned her not to tell anybody. Every day she is asked whether she has received anything to drink. The men in the village get suspicious and call for a meeting. They scold her and force her to divulge the secret. She takes them to the mountain and they find the giant bird.

They shoot the bird. Water appears from its body and the rivers and springs are filled.

We note in this Xhosa folktale the same kind of intimacy between birds, water and female fecundity that we have identified in "The Blue Crane and the waterhole" or "Sikhamba-ngenyanga". Only, by entrusting its secret to a young woman, this particular bird defies the council of men in the village. Why would a sky bird, deemed to be an image of masculinity, ally itself with the realm of women? Worse still, why would it betray men?

A similar kind of blurring of gender identity characterises Khiudogane, the sacred bird of the Byali girls' rites of passage amongst the Lovedu (Limpopo). On the one hand, this avian metaphor clearly forms part of a larger, more elaborate complex of symbols of water, life, rain and the mystic powers that were believed to control the survival of humans and nature (Krige and Krige 128, 132, 139). The dancing and other cult activities were organised for the benefit of the young female initiates. Its rites protected and honoured the institution of motherhood and women organised its pedagogic process. Also, metaphors indirectly or directly expressive of the bird cult were declared to have originated from a magical pool in the river. In fact, the terrifying bird itself was said to reside in the pool, together with all other mysteries or digoma of the school (Krige and Krige 135, 140). The crafting of the teaching aids and the costumes of the initiates, the building of the bird's residence, the production of the sacred flutes and the male dancing costumes required the use of bark, reeds, leaves and grass: materials that were procured from the river, the pool and its immediate surroundings (Davison 95). In short, the mighty Khiudogane evidently expressed, fostered and celebrated female fecundity.

On the other hand, one could just as easily link the symbolic discourse of the mysterious bird cult to the realm of men. The intricate costume of the bird creature and its enclosed living quarters were built by men. Only senior men were allowed 
to stay with it. Further, the bird monster's ritual performance was acted out by men assisted by initiates of the male circumcision school. The whistle language of the cult, performed by men, resembled a similar mode of communication in the gomana cult, run by men. Lastly, the terms of reference to the bird clearly emphasized its masculine identity. No wonder that the bird has been referred to by the Kriges (130, $232,140)$ as the mystery of the old men.

These instances of gender ambiguity raise the question as to how and why the same bird metaphor would serve the interests of both sexes. We discovered the answer in a more complex meaning of traditional avian symbolism and of the social processes of gender construction with which it was intertwined. Blacking's admirable ethnography of Venda girls' initiation provided the data that challenged our initial, dichotomous understanding.

\section{Beyond dichotomy: birds and the gender dialectic}

Blacking's $(26,77,163,221)$ survey of the Domba initiation includes five masculine sky birds. Two are straightforward images of male prowess: the kori bustard (dandila) and the vulture (danga). Meaningfully, the kori bustard was also referred to by the instructors as the puff-adder, which signified the male sexual organ. The remaining three (the martial eagle, the hammerhead and an unidentified species called $\mathrm{khu}$ wadzi) are ambiguous in that they were paired with the mysterious pool, the realm of female procreativity. They resembled the ambivalent avian creature in "The girl who defeated the rain", as well as Khiudogane, the great mystery in the Byali rites of passage.

All five masculine bird metaphors feature in an identical didactic context: lessons that were intended to emphasize the social and cosmological importance of procreativity, the central theme of girls' puberty rites (Blacking 216). In our understanding, the hammerhead, khuwadzi and the martial eagle were juxtaposed to the female pool image as companions or perhaps even as guardians in order to express the ideological construct of balance or complementarity between the sexes. The association between these three sky birds and the pool conveyed to the learners the notion that human procreation required the cooperative efforts of husbands and wives. We found numerous other symbolic pairs in the aphorisms, ritual songs and exercises of the Domba (see Blacking 80, 85, 101, 167, 173).

In contrast, the images of the kori bustard and the vulture defined men as sexual predators and signified sexual tension or opposition. Domba symbolism routinely defined men as scavengers and predators or depicted them as hunters who pursued women as their prey. Several ritual lessons defined the sexual union as an agonizing experience. Men, it was stated were ready "to crush the little bones" and "to stir the entrails" of the female novices. In other lessons the girls were told that men could "ram", "break", "pierce", "tear" and "rip apart" their sexual partners (Blacking 83, 84, 88, 91, 92). 
Some of the stories, and the metaphors which they contain, articulate the very same principle of tension between the sexes that was expressed in the discourse of initiation. We should not be surprised by this didactic analogy or continuity between folklore and rites of passage. After all, both the narrators and the instructors of the initiation school endeavoured to propagate similar cultural values or social norms (Dederen, "Redemption, Resistance, Rebellion: the three R's of African Folklore" 265-6).

Regarding gender opposition, it has been suggested by Kruger and Le Roux that the folktales of Southern Africa often depict a universe controlled by the patriarchy, in which women are preyed upon. Women are described as "perpetual minors" and their relations with the opposite sex are said to be portrayed in terms of "violent, primordial images of male aggression". On the other hand, it has aptly been emphasized by the same authors that women resisted oppression and used storytelling to defy the patriarchy (Kruger and Le Roux 7, 13, 15). We concur that women, far from being passive spectators or consumers of male ideologies, employed some of their narratives as a symbolic means to expose and counter unfair treatment by men. However, we believe that the symbolic "resistance" or "rebellion" against the patriarchy was of a subtle and implicit nature (Dederen, "Dog with a Collar" 94-5).

"The woman who stole the eagle", it was mentioned earlier on, exposes the favouritism displayed by husbands towards the youngest of the co-wives. By the same token, young women are reminded that they too cannot escape the retaliation of their husband, "the lion in the house". Other tales like "Sikhamba-ngenyanga" criticize men for being selfish and insensitive to the needs of their wives.

In "The woman and the mighty bird", we believe, yet another form of women's opposition to men transpires. The terrible bird that hides in the darkest part of the forest first tricks a woman into disobeying her husband and subsequently kills her. In doing so the bird sanctions the authority of the men in the village. The moral of the story is that men are not to be trusted. The creator of this story deployed, if not appropriated, the masculine bird image in order to expose the unfairness of men.

The fluidity of the magical bird in "The girl who defeated the drought" can be explained in terms of the strategy of appropriation too. Its empathic disposition towards the young female hero could be read as a manifestation of the principle of gender complementarity. On the other hand, it is equally feasible to assume, as we do, that the creator of the story has taken on the opposite sex by taking over its image of the sky bird.

Finally, the gender ambivalence that characterises Khiudogane can be accounted for by the fact that women and men can deploy the same symbol in opposing ways in order to suit their particular interests (see Turner 55-6; Dederen, "Dog with a Collar" 93). In this case, men may have created the great bird of the Byali in order to acquire patronage over women's rites of passage. Women, in response, might have simply appropriated and interpreted the great magical bird as "theirs". In sum, rituals, like 
stories, provided the battleground for the negotiation of gender construction. In traditional societies female and male comprised significant categories of symbolic classification, and gendering was used to make sense of the world. We propose that water and sky birds mirror the principles of gender opposition and balance in which the didactics of rites of passage and folklore was grounded.

\section{Conclusion}

The most surprising outcome of our engagement with the bird metaphor concerns the meaningful quality of ambiguity. Ambiguity is generally assumed to have been a distinctive feature of the symbolism of many a small-scale society. It has been accounted for in a variety of ways. Turner (43-4) believes it to result from the fact that symbols signified the complexity of the "human total." In San culture contradictions and ambivalence of meaning have been clarified with reference to the principles of shifting, renewal and transformation characteristic of ritual experience (Keeney and Keeney 65-6). Matthias Guenther (226-43) has proposed that vagueness and inchoateness of beliefs could be the result of tensions between social organisation and ideology. In this article ambivalent symbolism is explained in terms of the gender dialectic.

\section{Works Cited}

Interviews and recordings:

Engelbrecht, D. Interview, Department of Zoology, U of Limpopo, 2016.

M. M. M. Interview, Ga-Ramokgopa, Capricorn district, Limpopo, 2015.

Munyai, A. M. Interview, Pile, Vhembe district, Limpopo, 1995.

North Sotho song recorded at Mohlabaneng, Limpopo, January 1998. OLP/NoSo/11/I-98.

Tsonga story recorded at Malamulele, Limpopo, March 2001. OLP/Ts/32/III-01.

Venda song recorded at Tsianda, Limpopo, September 2003. OLP/Ve/71/IX-03.

Begler, E. B. "Sex, Status and Authority in Egalitarian Society." American Anthropologist vol. 80, 1978, pp. 571-88.

Bennun, N. The Broken String. The Last Words of an Extinct People. Viking, 2004.

Berglund, A. Zulu Thought-Patterns and Symbolism. Hurst, 1976.

Bernard, P. S. Messages from the deep: water divinities, dreams and diviners in Southern Africa. Diss. Rhodes U, 2010. http://hdl.handle.net/10962/d1007644.

Biesele, M. Women like meat: The Folklore and Foraging Ideology of the Kalahari Ju/'hoan. Wits U P, 1993.

Blacking, J. "The Songs, Mimes, Dances and Symbolism of Venda Girls' Initiation Schools." African Studies vol. 28, 1969, pp. 3-35, 69-118, 149-99, 216-66.

Corbeil, J. J. Mbusa. Sacred emblems of the Bemba. Ethnographica, 1982.

Davison, P. "Lovedu Material Culture." Annals of the South African Museum vol. 94, no. 3, 1984, pp. 41-201.

Dederen, J.-M. "A Dog with a Collar ... Field notes on an 'indigenous wedding gown'." Anthropology Southern Africa vol. 34, no. 3-4, 2011, pp. 89-95. DOI: https://doi.org/10.1080/23323256.2011.11500012. . "Redemption, Resistance, Rebellion: the three R's of African Folklore." Historia vol. 53, no. 1, 2008, pp. 260-7.

Eiselen, W.M. "Religious Beliefs and Practices." The Bantu-speaking Tribes of South Africa. An Ethnographical Survey. Ed. I. Schapera. Maskew Miller, 1937, pp. 247-70.

Garlake, P. S. Great Zimbabwe. Thames \& Hudson, 1973. 
Guenther, M. Tricksters and Trancers. Bushman Religion and Society. Indiana U P, 1999.

Heintze, B. “Der südrhodesischen dziva-Komplex." Anthropos vol. 62, no. 3-4, 1967, pp. 337-68.

Hertslet, J. Bantu Folk Tales. The African Bookman, 1946.

Hewitt, R. Structure, Meaning and Ritual in the Narratives of the Southern San. Wits U P, 1986.

Hoff, A. "The Water Bull of the /Xam." South African Archaeological Bulletin vol. 53, 1998, pp. 109-124.

Jordan, A. C. Tales from Southern Africa. U of California P, 1973.

Junod, H. A. The Life of a South African Tribe. Macmillan, 1927.

Keeney, B. and H. Keeney. "Reentry into First Creation: A Contextual Frame for the Ju/"hoan Bushman Performance of Puberty Rites, Storytelling and Healing Dance." Journal of Anthropological Research vol. 69, no. 1, 2013, pp. 65-86. http://www.jstor.org/stable/24393640.

Keyser, A. Venda sprokies: uit die volksmond oorvertel. Voortrekkerpers, 1949.

Krige, E. J. The Social System of the Zulus. Shuter \& Shooter, 1936.

Krige, E. J. and J. D. Krige. The Realm of a Rain-Queen. A Study of the Pattern of Lovedu Society. Juta, 1943.

Kruger, J. and I. le Roux. The Flamboyant Rooster and Other Tshivenda Song Stories. School of Music, North West U, 2007.

Kunene, D. P. Heroic Poetry of the Basotho. Oxford U P, 1971.

Lemekoana, J. M. and I. S. Masola. Sebešong. Centaur, 1988.

Lestrade, G. P. Some Venda Folk-Tales. Lovedale, 1949.

Makgalo, D. M., J. Z. Mothuši and S. A. Makopo. Mokga kgati ...! Actua, 1986.

Mashilo, P. M., V. M. Mashilo \& M. R. Mampuru. Ekwang tša koko le borakgolo. Kalahari, 2005.

Richards, A. I. Chisungu: A Girls' Initiation Ceremony among the Bemba of Northern Rhodesia. Faber and Faber, 1956.

Scheub, H. The Xhosa ntsomi. Clarendon, 1975.

Scott, J. W. Gender and the Politics of History. Columbia U P, 1999.

Silberbauer, G. B. "Marriage and the Girls' Puberty Ceremony of the G/wi Bushmen." Journal of the International African Institute vol. 33, no. 1, 1963, pp. 12-24.

Stayt, H. A. The Bavenda. Oxford U P, 1931.

Stefaniszyn, B. “The Hunting Songs of the Ambo." African Studies vol. 10, no. 1, 1951, pp. 1-12.

Turner, V. W. The Forest of Symbols. Ithaca, 1967.

Van Warmelo, N. J. Contributions towards Venda History, Religion and Tribal Ritual. Government Printers, 1932.

Witt, J. "Comments on Vukwe: a Zimbabwe Type Site in North-Eastern Botswana." The Digging Stick vol. 27 , no. 1,2010 , p. 13. 